\title{
Integration of Microgrids and Electric Vehicle Technologies in the National Grid as the Key Enabler to the Sustainable Development for Rwanda
}

\author{
Samuel Bimenyimana $\mathbb{D}^{1},{ }^{1}$ Chen Wang $\mathbb{D},{ }^{1}$ Aphrodis Nduwamungu $\left(\mathbb{D},{ }^{2}\right.$ \\ Godwin Norense Osarumwense Asemota $\mathbb{D}^{2}{ }^{2}$ Wellars Utetiwabo $\mathbb{D}^{1},{ }^{3}$ Chun-Ling Ho, ${ }^{1}$ \\ Jean De Dieu Niyonteze $\mathbb{D}^{4},{ }^{4}$ Noel Hagumimana $\mathbb{D}^{4},{ }^{4}$ Theobald Habineza $\mathbb{D},{ }^{5}$ \\ Waqar Bashir $\mathbb{D}^{6},{ }^{6}$ Cicilia Kemunto Mesa $\mathbb{D}^{7,8}$ and Yiyi Mo $\mathbb{D}^{1}$ \\ ${ }^{1}$ Huaqiao University, Intelligence and Automation in Construction Provincial Higher-Educational Engineering Research Centre, \\ 361021 Xiamen, China \\ ${ }^{2}$ Africa Centre of Excellence in Energy for Sustainable Development, University of Rwanda, Kigali, Rwanda \\ ${ }^{3}$ School of Education, University of Rwanda, Rwanda \\ ${ }^{4}$ Fujian Province Key Laboratory of Automotive Electronics and Electric Drive, Fujian University of Technology, \\ Fuzhou 350118, China \\ ${ }^{5}$ Department of Climate Change Observatory Secretariat, Ministry of Education, Kigali, Rwanda \\ ${ }^{6}$ School of Electrical Engineering and Automation, Tianjin Polytechnic University, China \\ ${ }^{7}$ Kenya Industrial Research and Development Institute, Nairobi, Kenya \\ ${ }^{8}$ Hello Renewables Ltd., Kigali, Rwanda \\ Correspondence should be addressed to Chen Wang; wch@hqu.edu.cn
}

Received 26 March 2021; Accepted 20 June 2021; Published 13 July 2021

Academic Editor: Kumarasamy Sudhakar

Copyright (C) 2021 Samuel Bimenyimana et al. This is an open access article distributed under the Creative Commons Attribution License, which permits unrestricted use, distribution, and reproduction in any medium, provided the original work is properly cited.

\footnotetext{
Rwanda is an East African Community (EAC) nation with rapid and remarkable past development in different sectors and still with the ambitious targets and plans to be achieved in the coming years ahead. The government plans universal electricity access by 2024 with $52 \%$ grid connection and $48 \%$ off-grid connections. In the transport sector, the concept of electric vehicles has been initiated and started in order to contribute to the UN Paris agreement and decrease the reliance of the transport sector on gaseous fuels which are one source of air pollutants leading to climate change, premature deaths, and morbidity associated with poor air quality. With higher electricity demand than the generation of the Rwandan power grid, different energy strategies are being developed with the overall objective to achieve the targeted universal energy access. In order to overcome the aforementioned issue, this paper proposes an integration of solar PV microgrids for the satisfaction of electric vehicle (EV) technology in Rwanda. Using HOMER Grid software, a managed EV charging station is simulated to a grid connected solar PV microgrid with storage in order to assess the economic impact. The results show that the proposed technology can lower the levelized cost (LCOE) of electricity by $139.7 \%$. This study can contribute to further research developments in either different perspectives related to the integration of distributed energy resources (DERs) with electric vehicles or studies related to affordable and environment-energy systems.
} 


\section{Introduction}

Current electricity access all over the world is about $89.589 \%$ of the population according to the statistics of the World Bank using the database of Sustainable Energy for All (SE4ALL) [1]. Ten years of continuous improvement enabled the global electrification rate to reach $89.6 \%$, with 153 million people gaining electricity access every year. Moreover, the greatest threat lies with over 573 million people remaining in the dark, especially those living in sub-Saharan Africa and in the remotest parts of the globe. Therefore, solar lighting, solar home systems, and more mini grids would be important at reaching the poor and the remotest of households. Universally, about 34 million people accessed basic electricity services using off-grid technologies in 2017 [2].

To date, access to electricity in Rwanda is estimated at 51\% and those not grid connected are about 14\% [3]. Rwanda has many distributed energy resources (DERs) like solar, biomass, hydro, methane gas in Lake Kivu, geothermal [4], and availability of feasible microgrids with different distributed energy resources like photovoltaics, battery storage, diesel generator, and electric vehicles are possible and implementable $[4,5]$.

Sustainable development is among key and crucial pillars for Rwanda and challenges for future community. By December 2015, around 195 countries ratified the Paris agreement to reduce greenhouse gas $(\mathrm{GHG})$ emissions as entrenched in the United Nations Framework Convention on Climate Change (UNFCC) [6]. Rwanda's mitigation effort comprises reducing the GHG emissions to $63.0 \%$ of the baseline over the period 2015-2030. This translates to 37.0\% GHGs emission reduction and 4.6 million tonnes $\left(\mathrm{CO}_{2}\right)$ in $2030[6,7]$.

From energy generation viewpoint, the government of Rwanda decided to increase the use of renewables through different technologies such as microgrids and electric vehicle technologies (which is still in its initial stages) in order to meet increasing energy demand and tackle gas emissions [8]. Additionally, electric vehicles and vehicle fuel economy implementation guidelines are significant assumptions over the coming decade for new vehicles entering the fleet, development of charging infrastructure, and electricity grid decarburization rate. The main aim of the paper is to analyze and enhance the contribution of microgrids and electric vehicles as key enablers for sustainable development. A firm EV station is analyzed by simulation considering that it is to be connected to a national power grid or a grid connected microgrid having storage, to assess the system contribution for affordable electricity tariff. The paper is organized into Introduction, Literature Review of Microgrids and Electric Vehicle Technologies, Methodology, Simulation Results, and Conclusion.

\section{Literature Review of Microgrids and Electric Vehicle Technologies}

Microgrids are small networks composed of different distributed energy resources, frequently linked to an integrated national grid that is able to operate in grid connected or islanded mode, and can be controlled by different control techniques such as traditional droop controller, modified droop controllers, and PQ controllers $[9,10]$.
2.1. Vehicle-to-Grid (V2G) Technology. Vehicle-to-Grid (V2G) technology discharges energy back to the grid to improve grid utilization, level demand, and improve reliability for utilities of the future. It can be used to support the utility grid services with stability increase and reliability of the network $[11,12]$. The control of active power $(P)$, and reactive power $(Q)$ between electric vehicles (EVs), and microgrids through bidirectional energy flows make them to be considered distributed energy storage (DES) units [13]. The owner of electric vehicle is able to control the charging and discharging times and, thus, can be used as sources of income because they can sell excess energy to the utility grid operators. V2G enables energy to be pushed back to the utility grid while Grid-to-Vehicle (G2V) is the process in which electric vehicles are charged via the power grid. Therefore, it is very easy to control and monitor power flow in Vehicle-toHome (V2H or V2B), and its implementation is not difficult compared to Vehicle-to-Grid because the reverse power interface is not required, but islanding detection capability and other power quality delivery detection interfaces. Different models of charging are considered depending upon the software package. Meanwhile, in energy planning, the four models considered include a dumb battery charger, flexible demand, smart charger, and V2G charging that contains EVs charging control based on different electricity tariff models [14]. Table 1 describes the power levels for the alternating and direct current for charging systems [15].

As the United Nations set guidelines for climate change and greenhouse gas emission limitations, many industries and researchers are still carrying out research on the development of different electric vehicles based on emissions and consumption [16].

2.2. Air Quality Standards in Rwanda. For climate change mitigations, every country should have an air quality standard based on the World Health Organization (WHO) guidelines, and air quality standards, set by Rwanda Environment Management Authority (REMA), are summarized in Table 2:

Table 3 describes the comparison of electric vehicles based on their driving component, energy sources, pros, and cons [16, 20-22]. Rajashekara discovered a new type of electric vehicles, which is slightly different from others and called plug-in fuel cell vehicle (PFCV) with a large battery and small fuel cell storage capacity that makes it a battery dominant car [19].

2.3. Grid-to-Vehicle (G2V) Technology. Grid-to-vehicle technology $(\mathrm{G} 2 \mathrm{~V})$ is used in the design of suitable charging algorithm to control charging, battery balance, and condition of charge estimation that enhance the battery life [23]. The vehicle-to-grid (V2G) technology is deployed by the plug-in electric vehicle (PHEV) to release energy to the grid to enhance grid utilization, balance demand, and improve reliability. Furthermore, it is an effective distributed energy resource (DER) [23, 24].

2.4. Smart Charging (V1G) Technology. Different researchers revealed that the utility grid must be innovative and upgraded and with Supervisory Control and Data 
TABLE 1: Alternating current (AC) and direct current (DC) power levels [15].

\begin{tabular}{|c|c|}
\hline AC charging levels & DC charging levels \\
\hline $\begin{array}{l}\text { AC level 1: } 120.0 \text { volt alternating current (VAC). Single-phase } \\
\text { (maximum) } 16.0 \text { amps (A); maximum 1.9 kilowatts (kW) }\end{array}$ & $\begin{array}{l}\text { DC level } 1: 200.0 \text { to } 450.0 \text { volt direct current (VDC), } \\
\text { maximum } 80.0 \mathrm{~A} \text { and maximum power is } 19.2 \mathrm{~kW}\end{array}$ \\
\hline $\begin{array}{l}\text { AC level 2: } 240.0 \mathrm{VAC} \text {, single phase, maximum } 80.0 \mathrm{~A} \text {, } \\
\text { maximum } 19.2 \mathrm{~kW}\end{array}$ & $\begin{array}{c}\text { DC level 2: } 200.0 \text { to } 450 \mathrm{VDC} \text {, maximum } 200.0 \mathrm{~A}, \\
\text { maximum } 90.0 \mathrm{~kW}\end{array}$ \\
\hline AC level 3: to be determined, can include AC three phases & $\begin{array}{l}\text { DC level 3: to be determined and may cover from } 200.0 \text { up } \\
\text { to } 600.0 \text { VDC, maximum } 400.0 \mathrm{~A} \text {, and maximum } 240.0 \mathrm{~kW}\end{array}$ \\
\hline
\end{tabular}

TABLE 2: Rwanda air quality standards versus WHO air quality guidelines [17-19].

\begin{tabular}{|c|c|c|c|}
\hline Type of pollutant & Averaging period (hours) & Rwanda standards $\left(\mu g / m^{3}\right)$ & $\begin{array}{l}\text { World Health Organization (WHO) } \\
\text { standards }\left(\mu \mathrm{g} / \mathrm{m}^{3}\right)\end{array}$ \\
\hline \multirow{2}{*}{ Carbon monoxide $(\mathrm{CO})$} & 1.0 & $30,000.0$ & $30,000.0$ \\
\hline & 8.0 & $10,000.0$ & $10,000.0$ \\
\hline \multirow{2}{*}{ Sulphur dioxide $\left(\mathrm{SO}_{2}\right)$} & 10.0 minutes & 500.0 & 500.0 \\
\hline & 24.0 hours & 125.0 & 125.0 \\
\hline \multirow{2}{*}{ Ozone $\left(\mathrm{O}_{3}\right)$} & 1.0 hour & 200.0 & 200.0 \\
\hline & 8.0 hours daily maximum & 120.0 & 120.0 \\
\hline \multirow{2}{*}{ Nitrogen dioxide $\left(\mathrm{NO}_{2}\right)$} & 1.0 hour & 200.0 & 200.0 \\
\hline & Annual & 40.0 & 40.0 \\
\hline \multirow{2}{*}{ Particulate matter $\left(\mathrm{PM}_{2.5}\right)$} & 24.0 hours & 75.0 & 75.0 \\
\hline & Annual & 35.0 & 35.0 \\
\hline \multirow{2}{*}{ Particulate matter $\left(\mathrm{PM}_{10}\right)$} & 24.0 hours & 100.0 & 100.0 \\
\hline & Annual & 50.0 & 50.0 \\
\hline
\end{tabular}

TABLe 3: Comparison of electric vehicles (EVs) [20-22].

\begin{tabular}{|c|c|c|c|c|}
\hline $\begin{array}{l}\text { Type of electric } \\
\text { vehicles }\end{array}$ & $\begin{array}{l}\text { Type of driving } \\
\text { component }\end{array}$ & Energy source & Pros & Cons \\
\hline $\begin{array}{l}\text { Solar electric } \\
\text { vehicles (SEV) }\end{array}$ & Electric motor & $\begin{array}{l}\text { Battery } \\
\text { ultra-capacitor }\end{array}$ & $\begin{array}{l}\text { (i) No expenses } \\
\text { (ii) Environment friendly } \\
\text { (iii) Zero net emissions } \\
\text { (iv) Low maintenance } \\
\text { (v) Able to utilize full power } \\
\text { at all speeds }\end{array}$ & $\begin{array}{l}\text { (i) Prices depend on } \\
\text { the quality } \\
\text { (ii) Dependence on } \\
\text { the solar radiation }\end{array}$ \\
\hline $\begin{array}{l}\text { Fuel cell electric } \\
\text { vehicles (FCEV) }\end{array}$ & Electric motor & Fuel cell & $\begin{array}{l}\text { (i) Zero net emissions } \\
\text { (ii) High efficiency } \\
\text { compared to others } \\
\text { slightly not expensive } \\
\text { (iii) Available in market } \\
\text { abundantly for some countries } \\
\text { (iv) Energy recovery from } \\
\text { regenerative braking }\end{array}$ & $\begin{array}{l}\text { (i)Production of fuel } \\
\text { (ii) Fueling facilities and } \\
\text { storage security concern } \\
\text { (iii) Standard } \\
\text { development } \\
\text { in process } \\
\text { (iv)Scalable for mass } \\
\text { manufacturing }\end{array}$ \\
\hline $\begin{array}{l}\text { Battery electric } \\
\text { vehicle (BEV) }\end{array}$ & Electric motor & (i) Ultra capacitor battery & $\begin{array}{l}\text { (i)Zero emissions } \\
\text { (ii) Charging and discharging } \\
\text { at convenient time and controlled } \\
\text { (iii) No dependence on oil } \\
\text { (iv) Income generation } \\
\text { (v)Prosumer option } \\
\text { (vi) Without gas and oil changes } \\
\text { (vii) Capacity to conveniently } \\
\text { charge at home } \\
\text { (viii)Rapid and steady } \\
\text { acceleration }\end{array}$ & $\begin{array}{l}\text { (i) Battery life } \\
\text { (ii) Battery price and } \\
\text { capacity as well } \\
\text { (iii) Charging time } \\
\text { (iv) Expensive in some } \\
\text { country of low and } \\
\text { middle income generally } \\
\text { (v) Availability of } \\
\text { charging stations }\end{array}$ \\
\hline $\begin{array}{l}\text { Hybrid electric } \\
\text { vehicles (HEV) }\end{array}$ & $\begin{array}{l}\text { Internal combustion } \\
\text { engines } \\
\text { Electric motor }\end{array}$ & $\begin{array}{l}\text { (i) Internal combustion } \\
\text { engines } \\
\text { (ii) Ultra capacitor } \\
\text { (iii) Battery }\end{array}$ & $\begin{array}{l}\text { (i) Composed of electrical and mechanical drive } \\
\text { trains } \\
\text { (ii) May be powered by both } \\
\text { electric supply and other fuels } \\
\text { (iii) Long range } \\
\text { (iv) Low emissions }\end{array}$ & $\begin{array}{l}\text { (i) Battery and engine } \\
\text { capacity optimization } \\
\text { (ii) High initial outlay }\end{array}$ \\
\hline $\begin{array}{l}\text { Plug-in hybrid electric vehicles } \\
\text { (PHEV) }\end{array}$ & Electric motor & $\begin{array}{l}\text { (i) Internal combustion } \\
\text { engines }\end{array}$ & $\begin{array}{l}\text { (i) Zero net emissions } \\
\text { (ii) Little consumption } \\
\text { (iii) Optimized performance }\end{array}$ & $\begin{array}{l}\text { (i) Higher initial cost } \\
\text { (ii) May be fed by a } \\
\text { power from electrical } \\
\text { and mechanical sources }\end{array}$ \\
\hline
\end{tabular}




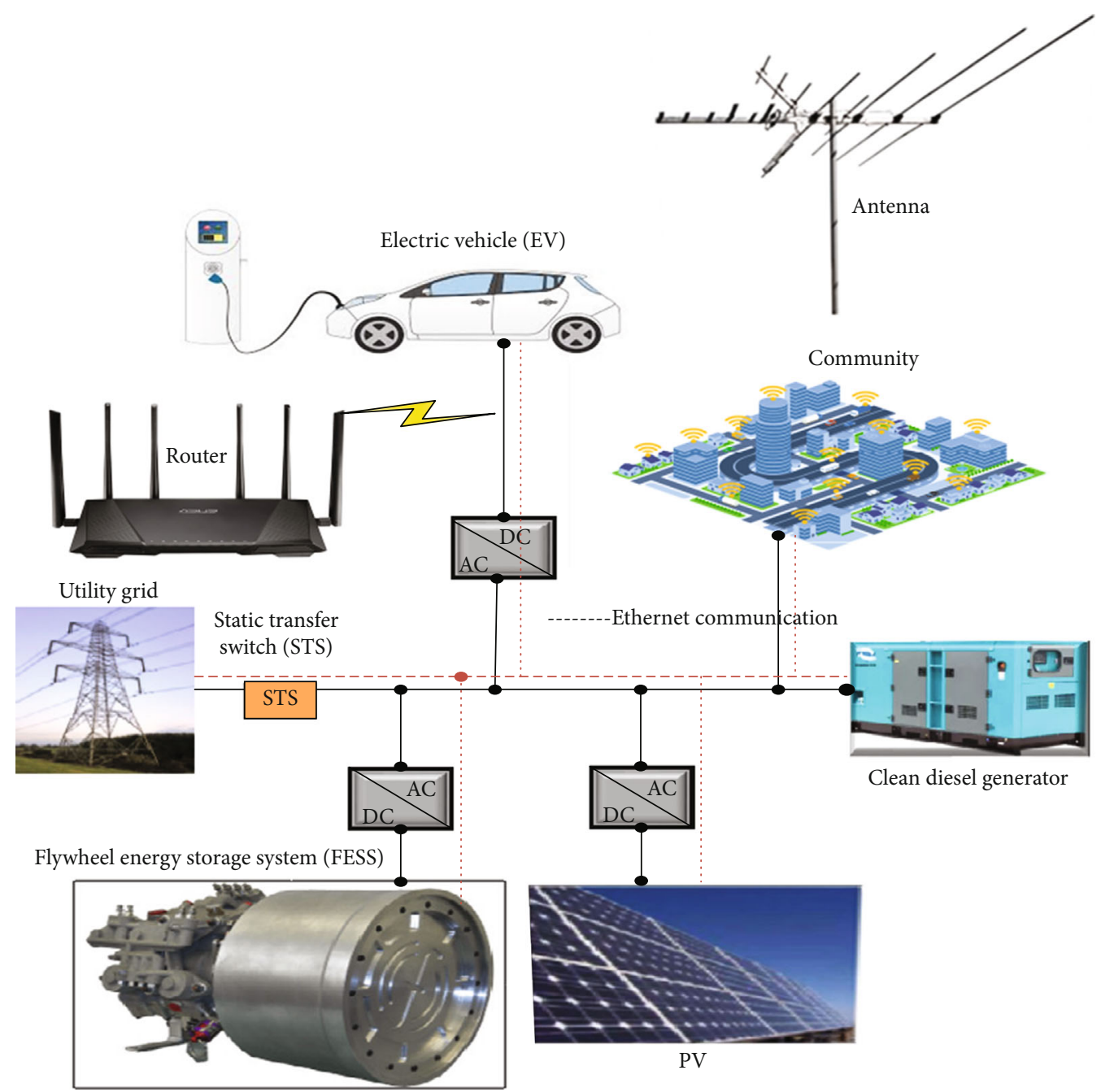

FIgURE 1: Diagram of microgrid with different distributed energy resources (DERs). Note: the figure is based on the authors' understanding and analysis of different energy technology exploitations and the desire of EV exploitation for Rwandan market; no source or reference is linked to the figure.

Acquisition (SCADA) software package integration in order to shift from traditional grid to the smart grid, so that it will be able to cooperate with future demand [25]. Smart charging (V1G) is a charging process in which electric vehicles, charging stations, and charging operators exchange data connections. Also, the charging stations can supervise, organize, and regulate EVs for enhanced time, charging power size, direction, and utility applications. V1G is applied in traffic congestion management, frequency control, and charging photovoltaic systems (PV) [25]. V2G can also supply electricity to the home (V2H), building (V2B), load (V2L), and grid (V2G). The major threats to V1G and V2G depend on the uniformity requirements and information exchange protocols between the various systems $[26,27]$.

2.5. Flywheel Energy Storage System (FESS) Technology. The flywheel energy storage system (FESS) is among the best storage technologies and keeps energy in terms of kinetic energy (KE) through electronics converters [28]. Flywheel is composed of converters (rectifiers and inverters), generator, motor bearings, protection cover, and control systems, built by differ- ent controllers in charge of controlling and maintaining charging, discharging cycle, and the status of flywheel $[29,30]$. Therefore, the speed of flywheel usually varies between 6000.0 and 12000.0 revolutions per minute (r.p.m.). Consequently, energy storages are varying between 2 Mega Joules (MJ) and $500 \mathrm{MJ}$, and so many types of energy storage devices, namely, batteries, super capacitors, and super conducting magnetic energy storage systems, and every storage device has its own disadvantages and advantages $[29,30]$.

2.6. Microgrid System with an Electric Vehicle. Contemporary transportation systems using fossil fuels based on conventional vehicles are being capability replaced by electric vehicles which are eco-friendly to the environment [23]. Based on the knowledge that EV technologies are still at their infancy and taking also into consideration that some forms of energy technologies (such as usage of flywheel energy storage systems) have not yet been introduced to the Rwandan energy market, the authors of this paper suggest a new technology which can also be analyzed for energy exploitation and EV technology as it is shown in Figure 1. The concept 


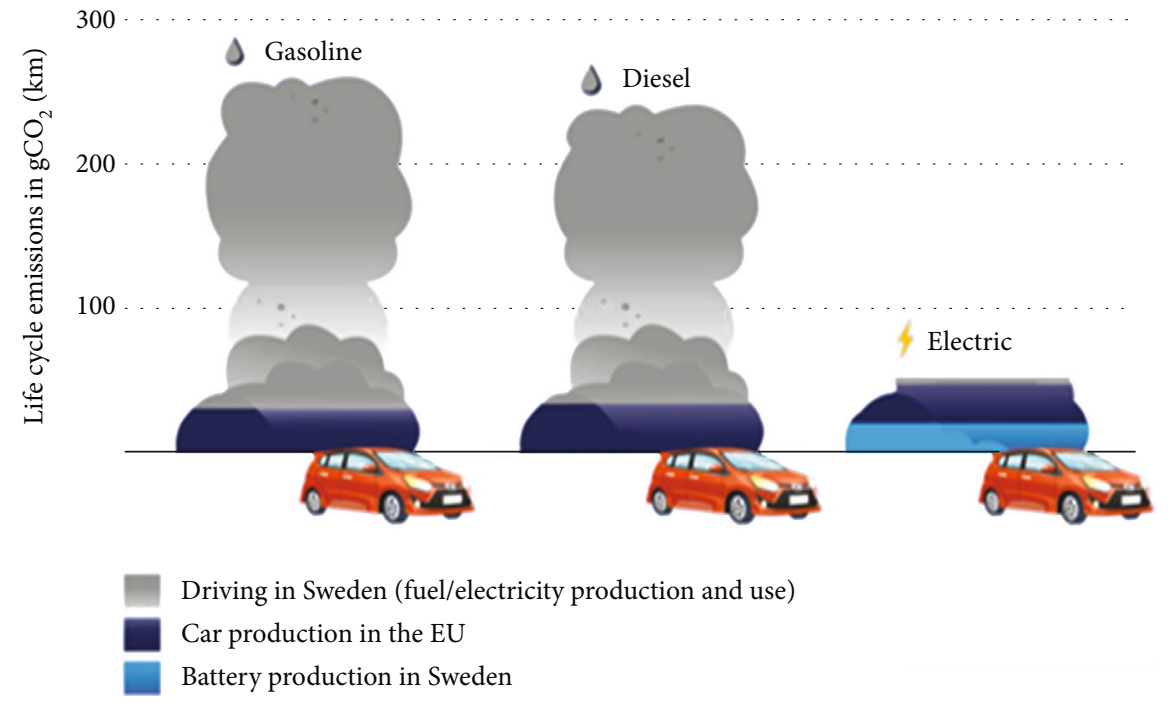

Figure 2: The lifetime carbon dioxide $\left(\mathrm{CO}_{2}\right)$ emission savings from electric vehicles (best case scenario) [33]
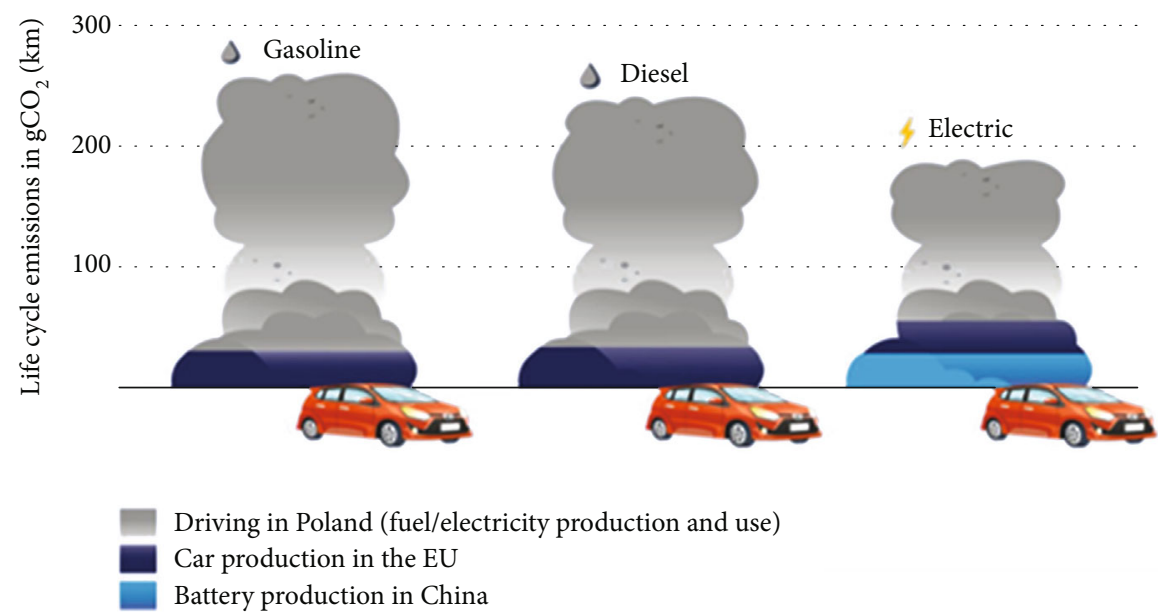

FIgure 3: The lifetime carbon dioxide $\left(\mathrm{CO}_{2}\right)$ effluent savings from electric vehicles (worst-case) [33].

300

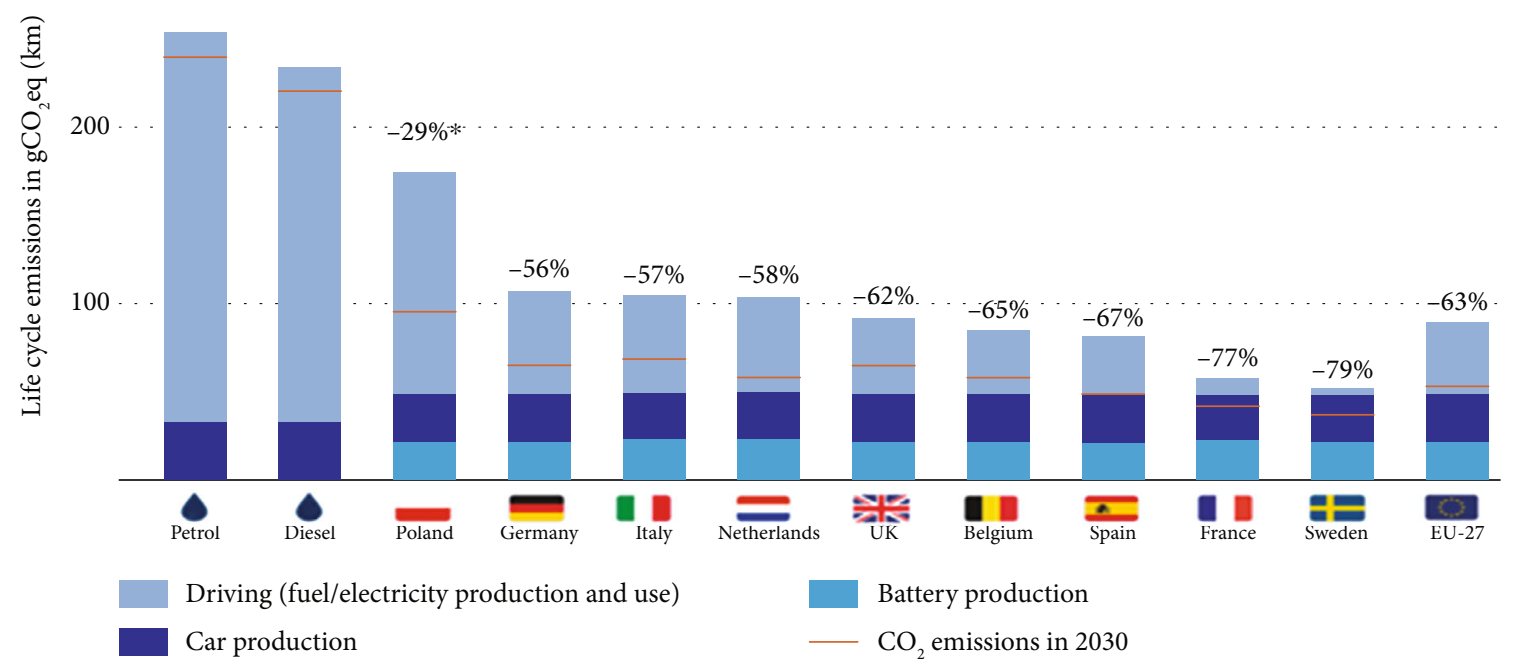

FIgure 4: The carbon dioxide $\left(\mathrm{CO}_{2}\right)$ savings in EVs compared to typical diesel and petrol car emissions [33, 34]. 







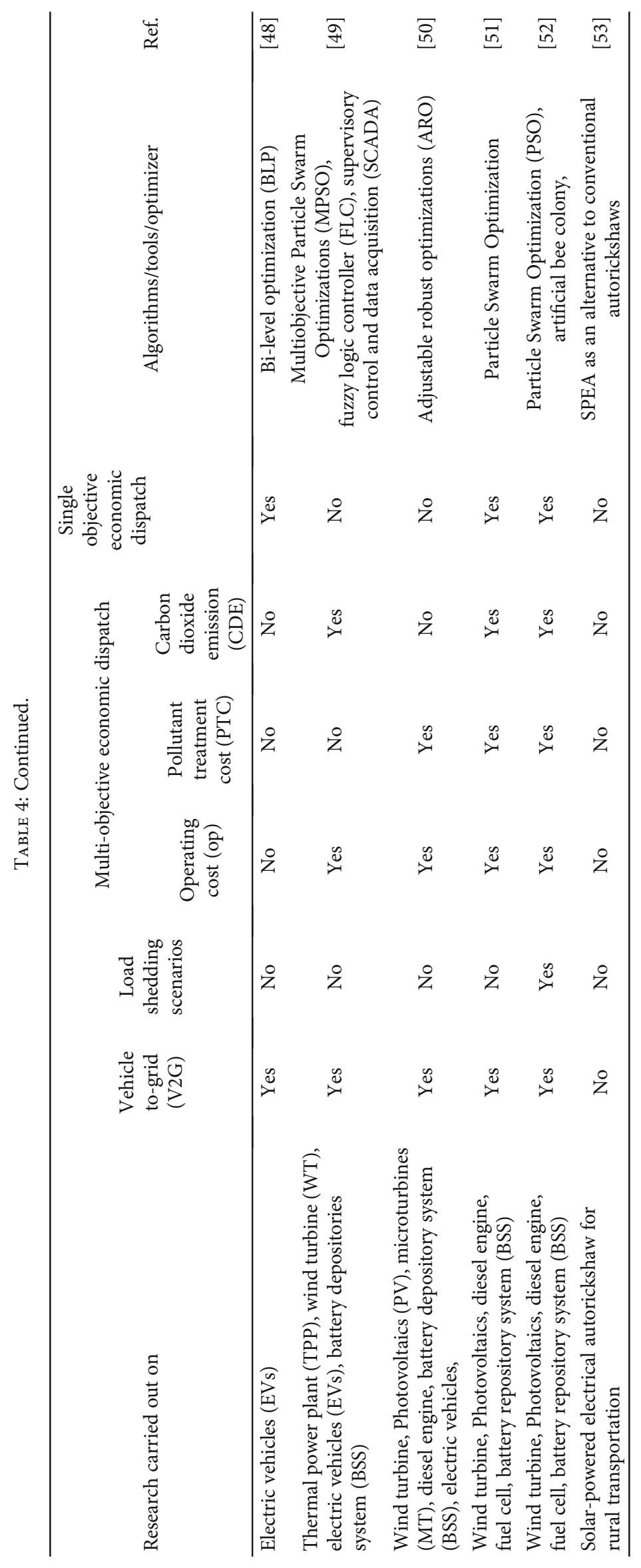




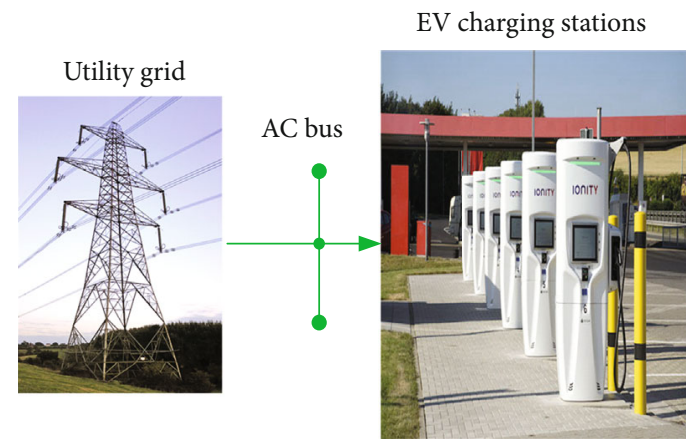

(a)

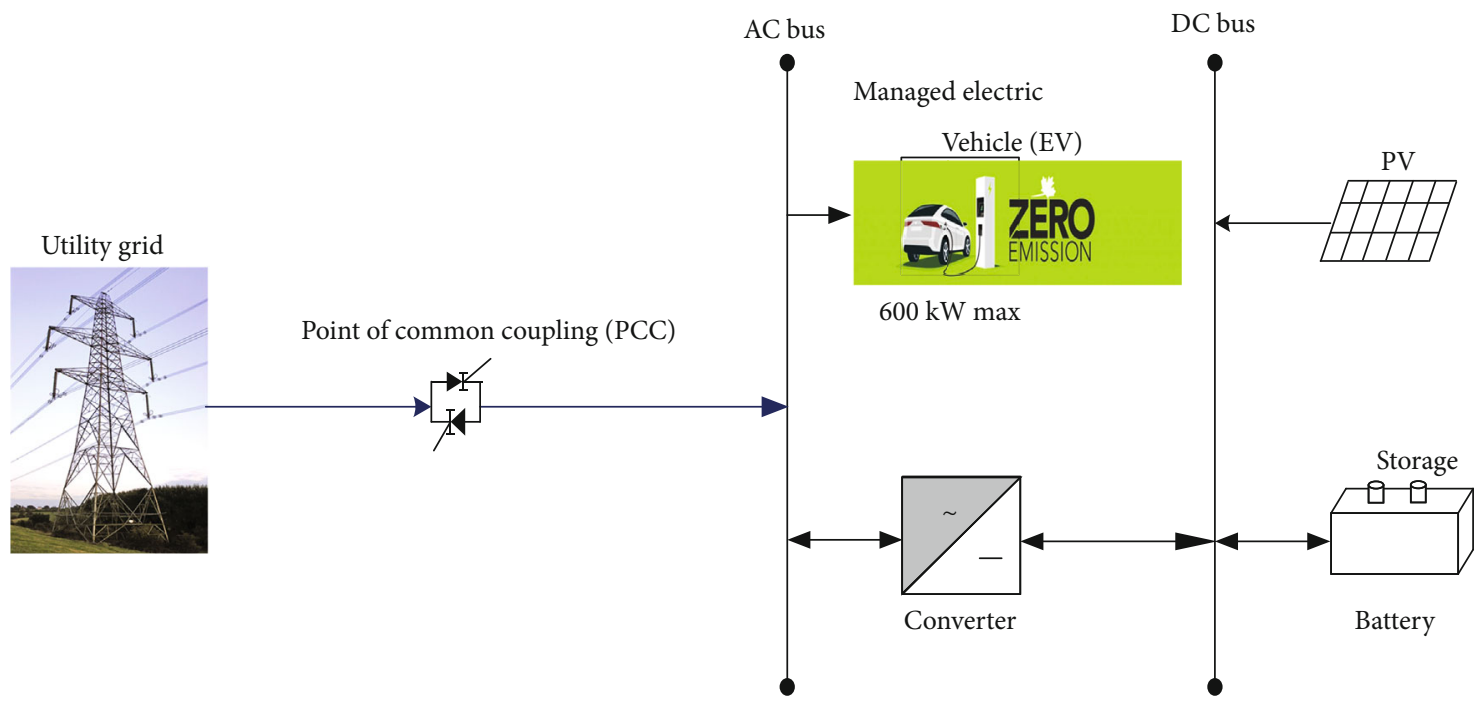

(b)

Figure 5: The proposed system (a) and the current system (b).

in Figure 1 can also be mimicked and perfected using the Hybrid Optimization of Multiple Energy Resources (Homer) grid software as it has different distributed energy resources such as PV, flywheel storage, clean diesel generator (CDG), and plug-in hybrid electric vehicles (PHEV). Every microgrid component is connected via a local network communication system based on wired and wireless technologies (WIFI). Figure 1 represents the microgrids composed of different distributed energy resources with electric vehicles. Every component is advantageous to the network, and the different constraints have been analyzed during the design, which is summarized below:

(i) At the beginning, microgrids and EVs are working in an islanded mode, which means that the PV and flywheel supply the community load while EVs are being charged

(ii) Whenever the PV system is incapable of supplying the load, at that time, the clean diesel generator will be able to feed the load

(iii) In case the PV is not able to supply the load and there is no fuel in the diesel generator but the EVs are charged, then the EVs can intervene and supply the community load

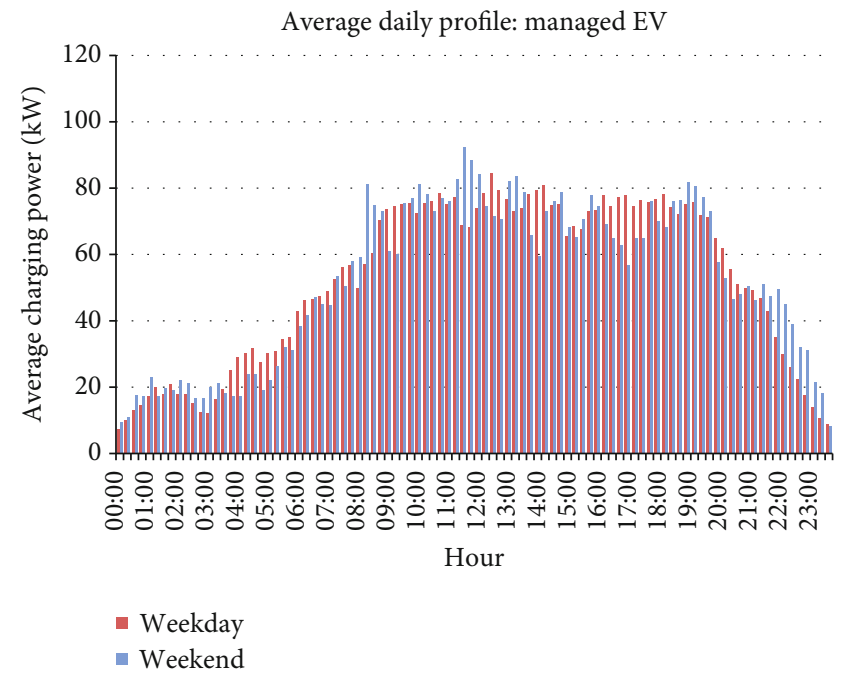

FIGURE 6: Average daily profile for the managed EV station.

(iv) In case PV, diesel generator, EVs, and flywheel are not able to satisfy the demand, the system will be halted, and priority loads will be supplied 


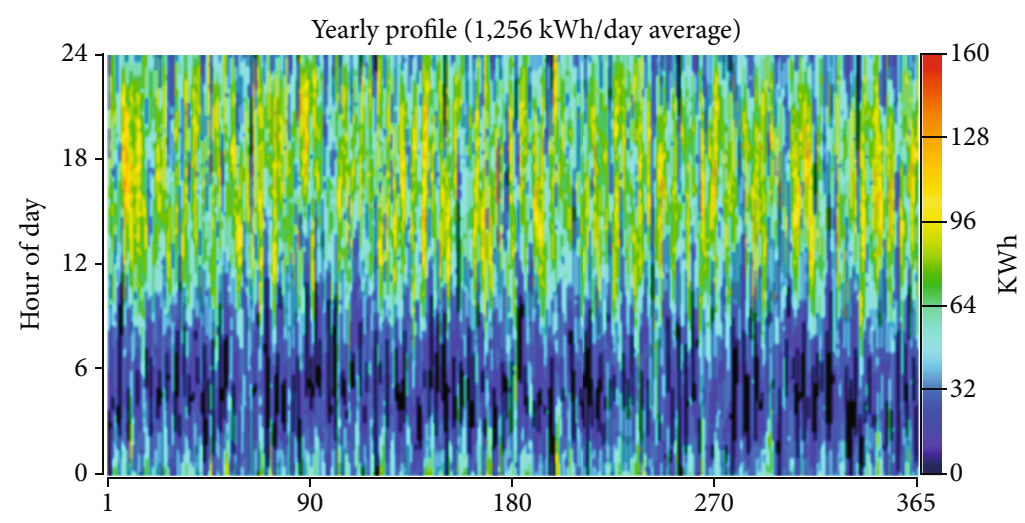

Figure 7: Annual load profile for the managed EV (average of $1258 \mathrm{kWh} /$ day).

(v) Microgrids will be responsible for controlling and managing variations of active power, reactive power, voltage, and frequency, which depend upon the type of controllers like traditional droop control and modified droop control

(vi) During utility grid supply, all parameters will be monitored by the utility grid, especially because the $\mathrm{PV}$, diesel generator, and EVs become incapable of satisfying the demand at that time. The utility grid will intervene depending upon the type of controllers, which are mostly PQ controllers, Virtual Synchronous Machines (VSG) or synchronverter method

2.7. Microgrid Operation. A microgrid operation (MGO) is a distributed class of electricity supply points and loads that typically connect and synchronize with the conventional wide area synchronous grid but could disconnect to an islanded mode through static transfer switch (STS) and function without support. As material or fiscal environments may demand, a ranked order structure could lead to a microgrid main controller (MMC) [31]. The diverse configurations and properties of the electronics in the microturbines, fuel cells, PV panels, wind including twice-fed induction generator technology (DFIG), and wind including permanent magnet synchronous machines (PMSM) technology make microgrids distinct from traditional power systems. Hence, energy repository equipment like flywheels and supercapacitors is interfaced to the grid to provide starting energy balance when the microgrid is islanded. Furthermore, these energy repositories provide active power whenever the microgrid either is islanded or swings in demand and supply occurs [31].

2.8. Technical Problems Based on V2G. The V2G technology, participation, and swift integration of electric vehicles (EVs) in the peak load periods of the network operations [32] provoke instability in the network and generate harmonics with frequencies greater than $50 \mathrm{~Hz}$ and $60 \mathrm{~Hz}$, high penetration of EVs in the utility grid which may cause network weakness, electric vehicle smart charging arrangement, and effects of

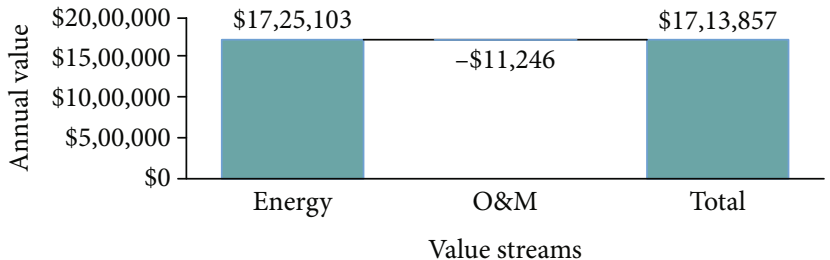

FIGURE 8: Categorized annual savings.

charging/discharging on EV battery and $\mathrm{V} 2 \mathrm{G}$ charger topology.

The bids and purchases of EVs have risen sharply because of the need of carmakers to satisfy the $\mathrm{CO}_{2}$ emission reduction stipulated by the EU car regulations of 2020 and 2021. Furthermore, within the coming decades, EVs are expected to experience so much mass marketing that the number of EVs on the EU roads would be over thirtyfold by 2030 . Based on the statistics, about $3.0 \%$ (1.3 million EVs) were sold by the end of 2019 and a total of 44.0 million electric cars are expected to be on the roads by 2030 . This translates to over 97.0\% EVs which would have been added to the fleet in the coming days and years to 2030. Consequent lifestyle changes would bring with them a collection of lifecycle analyses that measure EV pollutant emissions like carbon dioxide $\left(\mathrm{CO}_{2}\right)$, and battery charging/discharging cycles contrasted with traditional fossil fueled cars [33].

Investigators are advised not to use obsolete data in their research because unreliable data can deliberately confuse lifecycle assessments. The obsolete data were used to compare electric vehicles and traditional cars which use either a diesel generator or petrol which needs upgrading [33]. The transport and environment (T\&E) company have created detailed and useful analogies of electric, diesel, and petrol engines in distinctive car capacities between 2020 and 2030 as shown in Figure 2. Figure 2 is the lifetime plot of carbon dioxide $\left(\mathrm{CO}_{2}\right)$ emission savings from electric vehicles. In the European Union (EU), electric cars emit $80.0 \%$ less carbon dioxide $\left(\mathrm{CO}_{2}\right)$ than diesel and $81.0 \%$ than petrol [33].

Research indicates that the typical EU electric car has about three times superior performance than the traditional equivalence today. It is expected that electric cars will become 


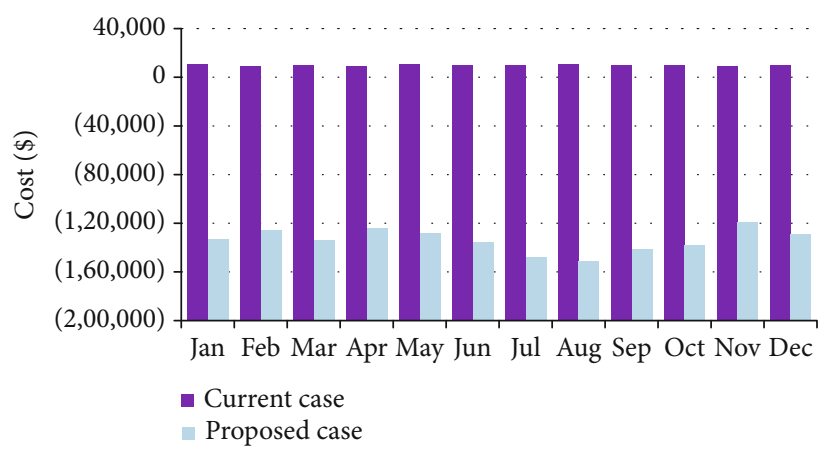

FIgURE 9: Monthly utility bills.

over four times cleaner than their traditional equivalents in the EU by 2030 [33].

Typical medium-sized EU electric cars sold in 2020 released about $90.0 \mathrm{gCO}_{2} \mathrm{e} / \mathrm{km}$, diesel car vented 234.0 $\mathrm{gCO}_{2} \mathrm{e} / \mathrm{km}$, and gasoline car emitted $253.0 \mathrm{gCO}_{2} \mathrm{e} / \mathrm{km}$ over their lifetimes, respectively. Typically, in the EU, the EV releases about 2.7 times less $\mathrm{CO}_{2}$ than the traditional car in 2020 (2.6 times less than diesel and 2.8 times less than gasoline). A storage battery produced with clean electricity reduces the electric car emission to $86.0 \mathrm{gCO}_{2} \mathrm{e} / \mathrm{km}$ or 2.7 3.0 times less. Electric cars were operated on clean renewable electricity (hydro power); then, the GHG emission reduces to 11.0 tons of $\mathrm{CO}_{2}(47.0 \mathrm{~g} / \mathrm{km})$, which is between 5.0 and 5.4 times less than diesel and gasoline equivalents, as shown in Figure 2 [33]. For substantial and leadership classes, the typical EU electric cars are between 2.8 and 3.1 times superior to their traditional equivalents [34].

At the worst, the battery storage is manufactured in China and used in electric vehicles operated on Poland's carbon demanding grids. Therefore, the lifespan effect rises to 41.0 tons of $\mathrm{CO}_{2}(182.0 \mathrm{~g} / \mathrm{km})$ and EVs are still $22.0 \%$ cleaner than their diesel equivalent and $28.0 \%$ cleaner than their gasoline equivalent as shown in Figure 3 [33]. A per European Union (EU) member state testing is possible in the device.

Figure $4[33,34]$ describes the carbon dioxide $\left(\mathrm{CO}_{2}\right)$ savings correlated with the typical diesel and petrol emissions. Up to date petrol and diesel cars emit almost 3.0 times more carbon dioxide $\left(\mathrm{CO}_{2}\right)$ than the typical European Union electric car $[33,34]$.

2.9. Levelized Cost Components. EV owners have multiple options for recharging their vehicles, for example, different places such as grocery stores, home, public, shopping malls, workplaces, and private parking area where the charging stations are installed. The vehicle purchase cost, on-fuel operations and maintenance cost, fuel cost, and, occasionally, transportation cost are considered in the overall cost of the $\mathrm{EV}$. The levelized cost is the likely vehicle age current value of the consumer cost per kilometer $(\mathrm{km})$ as depicted in equation (1). Therefore, the vehicle's leftover value is removed from consumer cost analysis. This value may be deducted from the total cost if considered. Some assumptions are made such as ignoring the vehicle residual value mainly because some data are not available conventionally for residual value
TABLE 5: Annual utility bills and savings by category.

\begin{tabular}{lcc}
\hline & Consumption charge & Total \\
\hline Base case & $\$ 118,946.00$ & $\$ 118,946.00$ \\
Proposed case & $-\$ 1.61 \mathrm{M}$ & $-\$ 1.61 \mathrm{M}$ \\
Annual savings & $\$ 1.73 \mathrm{M}$ & $\$ 1.73 \mathrm{M}$ \\
\hline
\end{tabular}

of battery electric vehicles (BEVs) [35-37]. Consequently, the general equation for levelized cost is written as follows:

$$
L C_{n}=\frac{\left(P C+\sum_{i=1}^{n}\left(\mathrm{FC}_{i}+\mathrm{OC}_{i}+\mathrm{AC}_{i}\right) /\left((1+\mathrm{DR})^{i-1}\right)\right)}{\sum_{i=1}^{n} \mathrm{DT}_{i}} .
$$

AC is the vehicle age substitute transportation cost (only for BEVs) (Rwandan Francs); DR is the 6.0\% deduction rate assumed for the analysis, in which a sensitivity analysis addresses the uncertainty; DT is vehicle age $(\mathrm{km})$ distance traveled, OC is vehicle age nonfuel operation and maintenance $(\mathrm{O} \& \mathrm{M})$ cost (Rwandan Francs); $\mathrm{LC}_{n}$ is the vehicle's levelized cost for $n$ years (Rwandan Francs $/ \mathrm{km}$ ); PC is vehicle purchase price (Rwandan Francs); and FC is the vehicle age fuel cost (Rwandan Francs) exclusively for battery electric vehicles (BEVs).

2.10. State of the Art Based on Research for Electric Vehicles and Contributions. Table 4 summarizes the state-of-the-art researches carried out and the gaps associated with electric vehicles (EVs) in [38] wherein the authors detailed the performance analysis and optimization of solar-powered Erickshaw for environmental sustainability in rural transportation and [39] wherein the authors described different types of fuel cell usually used in microgrids.

\section{Methodology}

The research in this paper used the HOMER Grid software, a powerful tool for detailed simulation concerning the needs (hourly, daily, monthly, and annual scenarios), capable of optimization (able to optimize for cost effectiveness), and able to carry out sensitivity analysis [53]. Given the fact that EV technology is still at its initial phases in Rwanda (configuration shown in Figure 5(a) where the EV is linked to the power grid), the system used the High E-Tech Smart Grid 


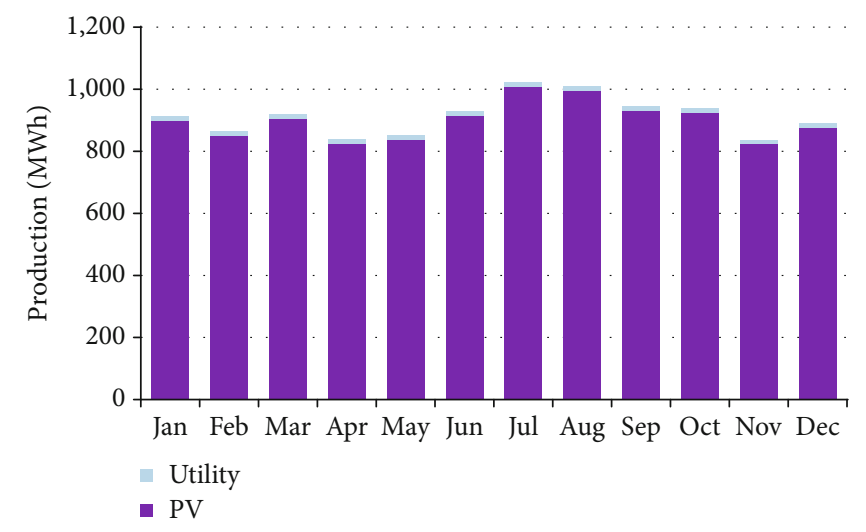

FIGURE 10: Utility and the solar PV microgrid electricity production.
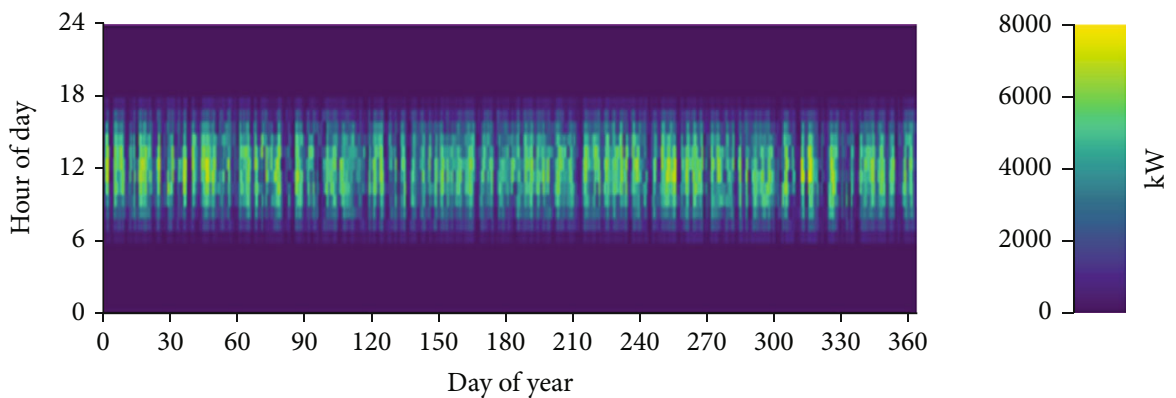

Figure 11: Daily electricity production over the year from the PV microgrid system.

Laboratory location resources of the African Centre of Excellence in Energy for Sustainable Development (ACE-ESD), University of Rwanda, Kigali, Rwanda, to simulate the gridconnected solar PV microgrid with storage and a managed EV station (as shown in Figure 5(a)), precisely located at KN 3 Avenue, Kigali, Rwanda ( $1^{\circ} 57.6^{\prime}$ S, 30 3.8 $\left.{ }^{\prime} \mathrm{E}\right)$. Rwanda electricity and feed-in tariffs data, NASA climatic weather conditions for solar energy generation, and National Renewable energy laboratory database were adopted as the HOMER resource database. A managed EV station with 100.0 as proportion of the EV population, $150.0 \mathrm{~kW}$ maximum charging power per EV (charger output power $\mathrm{kW}$ ), 40.0 chargers, and 7.0 hours connected mean time were obtained from HOMER software and incorporated into the Rwanda case study in order to study and analyze the impact of integrating solar PV microgrid and EV in the Rwandan network. Note that the managed EVs term used in the concept of this paper is well known as deferrable EV as it allows users to optimize their charging stations, lower their monthly utility bills, and have some flexibility for when the EV load is served [54]. Not only these data, there are also several research documents which were consulted by the authors to make the research work content in this paper more concise and communicative. Note that it was clarified for the whole body of this paper that the term "base case" refers to a system where the EV is connected directly to the national power grid for charging as shown in Figure 5(a), while the "proposed case" refers to the technology where the EV can be connected to the grid-connected solar PV microgrid for charging as shown in Figure 5(b).
TABLE 6: The EV charging load (managed EV).

\begin{tabular}{lc}
\hline Annual energy served & $459,250.0 \mathrm{MWh}$ \\
Peak load & $300.0 \mathrm{~kW}$ \\
Energy per session & $125.0 \mathrm{kWh}$ \\
Charging sessions per day & 10.1 \\
Charging sessions per year & $3,674.0$ \\
Average missed sessions per day & 0 \\
Utilization factor & $7.34 \%$ \\
Average session duration & $7.00 \mathrm{hr}$ \\
\hline
\end{tabular}

\section{Simulation Results}

Electricity generation through solar energy technologies is dependent on climatic weather conditions such as irradiance and clearness index (CI) which is the division output of the sun-oriented radiation that is transmitted through the atmosphere to strike the surface of the Earth; a dimensionless number between 0 and 1 and temperature variation were parameters used for the simulated location in the case study. For the location used in this research paper as the research object location, the average monthly Global Horizontal Irradiance (GHI) (which is the total solar radiation incident on a horizontal surface expressed in $\mathrm{kW} / \mathrm{m}^{2}$ /day) shows variation throughout the year and within the range between 4.457 and $5.348 \mathrm{kWh} / \mathrm{m}^{2} /$ day in which the overall annual average was $4.914 \mathrm{kWh} / \mathrm{m}^{2} /$ day for one month. The clearness index falls within the range of between 0.451 and 0.579 ; and the 


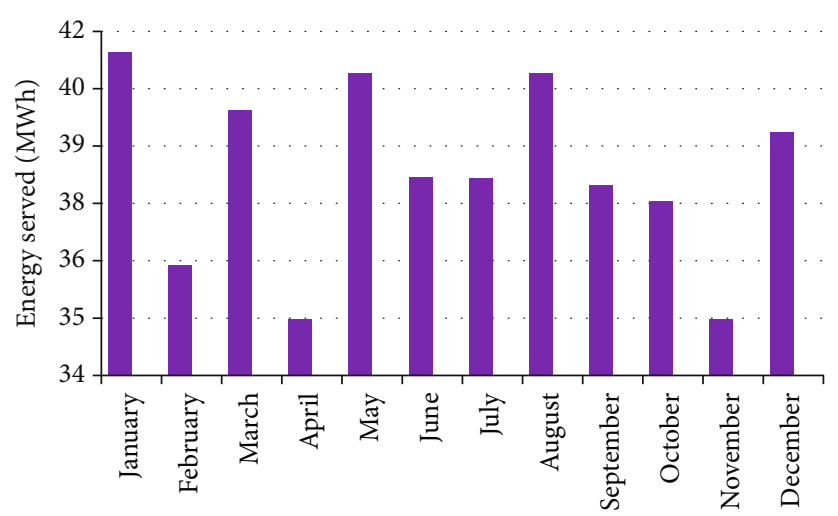

FiguRE 12: Energy served (MWh), monthly energy served to the managed EV.

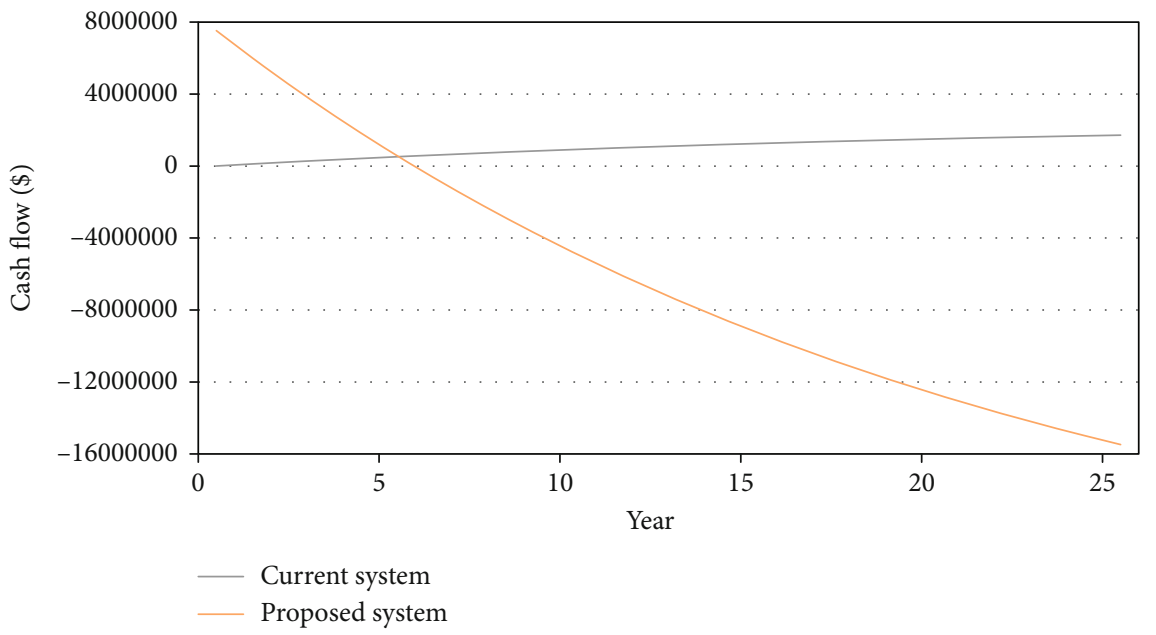

Figure 13: Cumulative cash flow over the project lifetime.

temperature is within the range 18.66 and $20.59^{\circ} \mathrm{C}$ with overall monthly average temperature of $19.583^{\circ} \mathrm{C}$ throughout the year. Such subjected climatic weather parameters and conditions are the major incentives for high output energy production from solar technologies once well exploited.

Figure 6 describes the average daily load profile for the managed EV stations as simulated in the case study used as the research object of this paper, and Figure 7 shows its variation throughout the year. The managed EV loads usually also referred as deferrable load by HOMER software permits clients and owners to improve EV charging stations and lower their electricity service bill month by month. The managed EV load as simulated in this research has an average of $1258.0 \mathrm{kWh} /$ day. The load consumption structure varies from hour to hour within a day, and it is shown that the minimum consumption was between $7.279 \mathrm{kWh}$ and $8.173 \mathrm{kWh}$ occurring around 00:00 pm (midnight), respectively, for both weekdays and weekends, the maximum consumption was between $84.82 \mathrm{kWh}$ and $92.307 \mathrm{kWh}$ occurring at 12:30 pm and 11:30 am, and the highest consumption of $9.0 \mathrm{kWh}$ occurs within 09:00 am up to 19:00 pm.

Figures 8 and 9 describe the categorized annual savings per year for the proposed system and the monthly electricity bills for both basic and proposed systems. With the proposed system, there will be annual energy savings with the value equal to US\$1,725,103.00, and it will decrease the cost for operation and maintenance (O\&M) which is considered the cost associated with operating and maintaining the proposed project to US\$-11,248.00 and the total annual overall energy value stream was US\$1,173,857.00. As it can be shown in Figure 9, the monthly electricity bill for the proposed system is lower than that for the basic (current) system for the whole year.

Table 5 describes the annual utility bills and savings by category for both the current system and the proposed system, and it can be shown that the consumption charge with the proposed system is around $-\$ 1.6 \mathrm{M}$ while for the base case system is estimated at $\$ 118,946$ which results in overall annual saving for the consumption charge equals $\$ 1.73 \mathrm{M}$. Note that the base case is the EV connection to the grid, and the proposed case is the EV connection to a grid-connected system with solar PV microgrid with its storage.

Figure 10 describes the monthly electricity production as expressed in MWh for both the utility grid and the PV system, and Figure 11 is the daily electricity production from the PV system over a period of one year with hourly details for one day. The minimum electricity production required from the grid of $10.995 \mathrm{MWh}$ occurred during November, while for the PC system, a minimum production of 823.731 


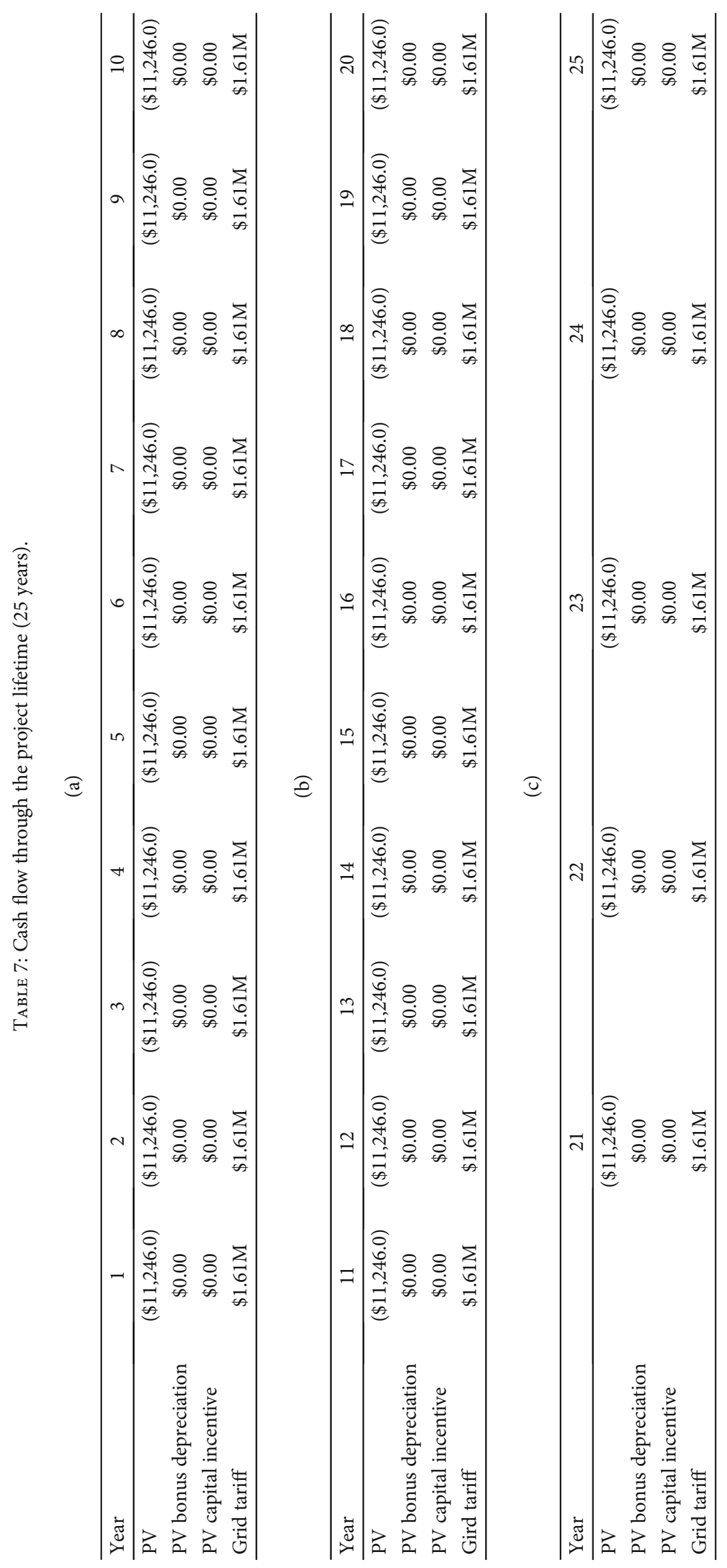


TABLE 8: Utility monthly summary for the base case.

\begin{tabular}{|c|c|c|c|c|c|c|c|c|c|c|}
\hline Month & $\begin{array}{c}\text { Energy } \\
\text { purchased } \\
(\mathrm{kWh})\end{array}$ & $\begin{array}{l}\text { Energy sold } \\
\text { (kWh) }\end{array}$ & $\begin{array}{c}\text { Net energy } \\
\text { purchased (kWh) }\end{array}$ & $\begin{array}{l}\text { Peak load } \\
\quad(\mathrm{kW})\end{array}$ & $\begin{array}{l}\text { Energy } \\
\text { charge }\end{array}$ & $\begin{array}{l}\text { Demand } \\
\text { charge }\end{array}$ & $\begin{array}{l}\text { Fixed } \\
\text { charge }\end{array}$ & $\begin{array}{l}\text { Minimum } \\
\text { charge }\end{array}$ & Taxes & Total \\
\hline January & $41,125.0$ & 0.0 & $41,125.0$ & 300.0 & $\$ 10,651.0$ & $\$ 0.0$ & $\$ 0.0$ & $\$ 0.0$ & $\$ 0.0$ & $\$ 10,651.0$ \\
\hline February & $36,125.0$ & 0.0 & $36,125.0$ & 300.0 & $\$ 9,356.0$ & $\$ 0.0$ & $\$ 0.0$ & $\$ 0.0$ & $\$ 0.0$ & $\$ 9,356.0$ \\
\hline March & $39,750.0$ & 0.0 & $39,750.0$ & 300.0 & $\$ 10,295.0$ & $\$ 0.0$ & $\$ 0.0$ & $\$ 0.0$ & $\$ 0.0$ & $\$ 10,295.0$ \\
\hline April & $34,875.0$ & 0.0 & $34,875.0$ & 300.0 & $\$ 9,033.0$ & $\$ 0.0$ & $\$ 0.0$ & $\$ 0.0$ & $\$ 0.0$ & $\$ 9,033.0$ \\
\hline May & $40,625.0$ & 0.0 & $40,625.0$ & 300.0 & $\$ 10,522.0$ & $\$ 0.0$ & $\$ 0.0$ & $\$ 0.0$ & $\$ 0.0$ & $\$ 10,522.0$ \\
\hline June & $38,200.0$ & 0.0 & $38,200.0$ & 300.0 & $\$ 9,894.0$ & $\$ 0.0$ & $\$ 0.0$ & $\$ 0.0$ & $\$ 0.0$ & $\$ 9,894.0$ \\
\hline July & $38,175.0$ & 0.0 & $38,175.0$ & 300.0 & $\$ 9,887.0$ & $\$ 0.0$ & $\$ 0.0$ & $\$ 0.0$ & $\$ 0.0$ & $\$ 9,887.0$ \\
\hline August & $40,625.0$ & 0.0 & $40,625.0$ & 300.0 & $\$ 10,522.0$ & $\$ 0.0$ & $\$ 0.0$ & $\$ 0.0$ & $\$ 0.0$ & $\$ 10,522.0$ \\
\hline September & $38,000.0$ & 0.0 & $38,000.0$ & 300.0 & $\$ 9,842.0$ & $\$ 0.0$ & $\$ 0.0$ & $\$ 0.0$ & $\$ 0.0$ & $\$ 9,842.0$ \\
\hline October & $37,625.0$ & 0.0 & $37,625.0$ & 300.0 & $\$ 9,745.0$ & $\$ 0.0$ & $\$ 0.0$ & $\$ 0.0$ & $\$ 0.0$ & $\$ 9,745.0$ \\
\hline November & $34,875.0$ & 0.0 & $34,875.0$ & 300.0 & $\$ 9,033.0$ & $\$ 0.0$ & $\$ 0.0$ & $\$ 0.0$ & $\$ 0.0$ & $\$ 9,033.0$ \\
\hline December & $39,250.0$ & 0.0 & $39,250.0$ & 300.0 & $\$ 10,166.0$ & $\$ 0.0$ & $\$ 0.0$ & $\$ 0.0$ & $\$ 0.0$ & $\$ 10,166.0$ \\
\hline
\end{tabular}

TABLE 9: Utility monthly summary for the proposed system.

\begin{tabular}{|c|c|c|c|c|c|c|c|c|c|c|}
\hline Month & $\begin{array}{c}\text { Energy } \\
\text { purchased } \\
(\mathrm{kWh})\end{array}$ & $\begin{array}{c}\text { Energy } \\
\text { sold (kWh) }\end{array}$ & $\begin{array}{c}\text { Net energy } \\
\text { purchased (kWh) }\end{array}$ & $\begin{array}{l}\text { Peak } \\
\text { load } \\
(\mathrm{kW})\end{array}$ & $\begin{array}{l}\text { Energy } \\
\text { charge }\end{array}$ & $\begin{array}{l}\text { Demand } \\
\text { charge }\end{array}$ & $\begin{array}{l}\text { Fixed } \\
\text { charge }\end{array}$ & $\begin{array}{l}\text { Minimum } \\
\text { charge }\end{array}$ & Taxes & Total \\
\hline January & $14,700.0$ & $826,677.0$ & $-811,977.0$ & 300.0 & $-\$ 133,421.0$ & $\$ 0.0$ & $\$ 0.0$ & $\$ 0.0$ & $\$ 0.0$ & $-\$ 133,421.0$ \\
\hline February & $13,149.0$ & $776,038.0$ & $-762,889.0$ & 300.0 & $-\$ 125,417.0$ & $\$ 0.0$ & $\$ 0.0$ & $\$ 0.0$ & $\$ 0.0$ & $-\$ 125,417.0$ \\
\hline March & $13,496.0$ & $825,538.0$ & $-812,042.0$ & 300.0 & $-\$ 133,544.0$ & $\$ 0.0$ & $\$ 0.0$ & $\$ 0.0$ & $\$ 0.0$ & $-\$ 133,544.0$ \\
\hline April & $12,666.0$ & $765,615.0$ & $-752,949.0$ & 300.0 & $-\$ 123,811.0$ & $\$ 0.0$ & $\$ 0.0$ & $\$ 0.0$ & $\$ 0.0$ & $-\$ 123,811.0$ \\
\hline May & $13,684.0$ & $790,264.0$ & $-776,580.0$ & 300.0 & $-\$ 127,640.0$ & $\$ 0.0$ & $\$ 0.0$ & $\$ 0.0$ & $\$ 0.0$ & $-\$ 127,640.0$ \\
\hline June & $13,472.0$ & $835,826.0$ & $-822,354.0$ & 300.0 & $-\$ 135,258.0$ & $\$ 0.0$ & $\$ 0.0$ & $\$ 0.0$ & $\$ 0.0$ & $-\$ 135,258.0$ \\
\hline July & $14,305.0$ & $914,351.0$ & $-900,046.0$ & 300.0 & $-\$ 148,077.0$ & $\$ 0.0$ & $\$ 0.0$ & $\$ 0.0$ & $\$ 0.0$ & $-\$ 148,077.0$ \\
\hline August & $14,004.0$ & $933,383.0$ & $-919,379.0$ & 300.0 & $-\$ 151,314.0$ & $\$ 0.0$ & $\$ 0.0$ & $\$ 0.0$ & $\$ 0.0$ & $-\$ 151,314.0$ \\
\hline September & $13,368.0$ & $871,782.0$ & $-858,414.0$ & 300.0 & $-\$ 141,253.0$ & $\$ 0.0$ & $\$ 0.0$ & $\$ 0.0$ & $\$ 0.0$ & $-\$ 141,253.0$ \\
\hline October & $12,789.0$ & $852,903.0$ & $-840,114.0$ & 300.0 & $-\$ 138,269.0$ & $\$ 0.0$ & $\$ 0.0$ & $\$ 0.0$ & $\$ 0.0$ & $-\$ 138,269.0$ \\
\hline November & $10,695.0$ & $734,075.0$ & $-723,379.0$ & 300.0 & $-\$ 119,086.0$ & $\$ 0.0$ & $\$ 0.0$ & $\$ 0.0$ & $\$ 0.0$ & $-\$ 119,086.0$ \\
\hline December & $13,017.0$ & $797,812.0$ & $-784,794.0$ & 300.0 & $-\$ 129,065.0$ & $\$ 0.0$ & $\$ 0.0$ & $\$ 0.0$ & $\$ 0.0$ & $-\$ 129,065.0$ \\
\hline Annual & $159,347.0$ & $9,924,264.0$ & $-9,764,917.0$ & 300.0 & $-\$ 1.61 \mathrm{M}$ & $\$ 0.0$ & $\$ 0.0$ & $\$ 0.0$ & $\$ 0.0$ & $-\$ 1.61 \mathrm{M}$ \\
\hline
\end{tabular}

MWh occurred in April and the maximum PV production of 1008.212 MWh occurred in July and 14.699 MWh in January, respectively, for the PV system and the utility grid. The PV system has a nominal capacity of $7,497.0 \mathrm{~kW}$. The annual production was $10,762,281.0 \mathrm{kWh} / \mathrm{yr}$; capital cost, $\$ 10.8 \mathrm{mil}-$ lion; specific yield, $1436.00 \mathrm{kWh} / \mathrm{kW}$; and maintenance cost, $\$ 11,246.00$ per year.

As given by the simulation results and as shown in Table 6, the annual energy consumption of this EV depot is $459,250.0 \mathrm{kWh}$ and the peak load is $300.0 \mathrm{~kW}$. The 10.1 charging sessions per day are supplied through 40.0 chargers, each capable of providing $150.0 \mathrm{~kW}$ maximum power output. The average session duration is 7.0 hours. The electric vehicles served by this depot have the following charging characteristics: $100.0 \%$ percentage of EV population, $150.0 \mathrm{~kW}$ maximum charging power per EV, and the $125.0 \mathrm{kWh}$ as average required energy.
Figure 12 describes the energy served in Megawatts hour for every month to the managed EV load where it kept fluctuating within the year. The highest $41.125 \mathrm{MWh}$ was achieved during January, and the lowest $34.875 \mathrm{MWh}$ occurred during April and November, respectively. Figure 13 represents the cumulative cash flow over the project lifetime, and Table 7 describes in detail the cash flow through the project lifetime over 25 years. It can be seen from Figure 13 that the cost (cash flow) for the base system slightly increases as time goes on while the cost with the proposed system greatly decreases with the project time frame period. Tables 8 and 9 describe the utility monthly summary for both the base system and the proposed system, respectively. It can be shown in Table 9, through peak load shaving of the PV system on the 300.0 $\mathrm{kW}$ peak load each month which led to a good system profit through energy sold, energy purchased, net energy purchased (kWh), energy charge, and the overall system total. 


\section{Conclusion}

The geographical location of Rwanda promises a good and fruitful output of solar energy once well and highly exploited. The study in this research proves it through an integrated solar PV microgrid connected to the national power grid with a managed EV charging station. The proposed technology once implemented promises the reduction of NPC from $\$ 1,715,610$ to $-\$ 15,480,080$ and the LCOE from $\$ 0.259 / \mathrm{kWh}$ to $-\$ 0.103 / \mathrm{kWh}$ all contributing to affordable and reliable energy system (the negative value of levelized cost of electricity and net total net present cost means that the income obtained from selling electricity to grid is more than the money spent to purchase electricity from the grid; and this indicates that the revenues exceed the costs). The solar energy system (integrating a solar PV system to a grid for the EV charging) as proposed in this research can lead to an efficient increase of national energy resource exploitation in the Rwanda, resulting in reliable, affordable, and sustainable energy access to all the citizens, and is known to be reliable and affordable and to have pillar sustainable development.

\section{Data Availability}

The data used in this research are available upon the request from the corresponding author.

\section{Conflicts of Interest}

The authors declare that they have no conflicts of interest.

\section{Acknowledgments}

The authors are grateful to Quanzhou Tongjiang Scholar Special Fund for the financial support through grant number 600005-Z17X0234; Quanzhou Science and Technology Bureau for the financial support through grant number 2018Z010; Huaqiao University through grant numbers 17BS201 and 605-50Y14007; and the Fujian Provincial Department of Science and Technology for the financial support through grant 2018J05121.

\section{References}

[1] The World Bank, "Access to electricity (\% of population)," https://data.worldbank.org/indicator/EG.ELC.ACCS.ZS?end= 2018\&start $=1990 \&$ view $=$ chart.

[2] World Health Organization, "More people have access to electricity than ever before, but world is falling short of sustainable energy goals," https://www.who.int/news-room/detail/21-052019-more-people-have-access-to-electricity-than-everbefore-but-world-is-falling-short-of-sustainable-energy-goals.

[3] J. Mugisha, M. A. Ratemo, B. C. Keza, and H. Kahveci, “Assessing the opportunities and challenges facing the development of off-grid solar systems in Eastern Africa: the cases of Kenya, Ethiopia, and Rwanda," Energy Policy, vol. 150, p. 112131, 2021.
[4] S. Bimenyimana, G. N. Asemota, and L. Li, "The state of the power sector in Rwanda: a progressive sector with ambitious targets," Frontiers in Energy Research, vol. 6, p. 68, 2018.

[5] S. Bimenyimana, G. N. O. Asemota, J. D. D. Niyonteze, C. Nsengimana, P. J. Ihirwe, and L. Li, "Photovoltaic solar technologies: solution to affordable, sustainable, and reliable energy access for all in Rwanda," International Journal of Photoenergy, vol. 2019, Article ID 5984206, 29 pages, 2019.

[6] FCCC, U, "FCCC. CP/2015/L. 9/Rev. 1: Adaptation of the Paris Agreement," 2015, February 2014, http://unfccc.int/ resource/docs/2015/cop21/eng/109r01.pdf.

[7] S. G. Yoon and S. G. Kang, "Economic microgrid planning algorithm with electric vehicle charging demands," Energies, vol. 10, no. 10, p. 1487, 2017.

[8] Volkswagen, "First for Africa: Volkswagen and Siemens launch joint electric mobility pilot project in Rwanda," https://www.volkswagen-newsroom.com/en/press-releases/ first-for-africa-volkswagen-and-siemens-launch-jointelectric-mobility-pilot-project-in-rwanda-5510.

[9] A. Nduwamungu, "Review on the coordination and energy management of microgrids broad based on PQ controller and droop control. Some useful information is given in this paper," Open Access Library Journal, vol. 4, no. 7, p. 1, 2017.

[10] N. Aphrodis, E. Ntagwirumugara, B. J. M. Vianney, and F. Mulolani, "Design, control and validation of a PV system based on supervisory control and data acquisition (SCADA) viewer in smartgrids," in 2019 5th International Conference on Control, Automation and Robotics (ICCAR), pp. 23-28, Beijing, China, 2019, April.

[11] M. Jun and A. J. Markel, "Simulation and analysis of vehicleto-grid operations in microgrid," in 2012 IEEE Power and Energy Society General Meeting, pp. 1-5, San Diego, CA, USA, 2012, July.

[12] M. H. Sarparandeh and M. Ehsan, "Pricing of vehicle-to-grid services in a microgrid by Nash bargaining theory," Mathematical Problems in Engineering, vol. 2017, Article ID 1840140, 11 pages, 2017.

[13] M. Bayati, M. Abedi, G. B. Gharehpetian, and M. Farahmandrad, "Short-term interaction between electric vehicles and microgrid in decentralized vehicle-to-grid control methods," Protection and Control of Modern Power Systems, vol. 4, no. 1, pp. 1-11, 2019.

[14] A. Šare, G. Krajačić, T. Pukšec, and N. Duić, "The integration of renewable energy sources and electric vehicles into the power system of the Dubrovnik region," Energy, Sustainability and Society, vol. 5, no. 1, p. 27, 2015.

[15] SAE, "SAE International Releases Updated Visual Chart for Its "Levels of Driving Automation" Standard for Self-Driving Vehicles," https://www.sae.org/news/press-room/2018/12/ sae-international-releases-updated-visual-chart-for-its- $\% \mathrm{E} 2 \%$ $80 \% 9$ Clevels-of-driving-automation $\% \mathrm{E} 2 \% 80 \% 9 \mathrm{D}$-standardfor-self-driving-vehicles.

[16] S. A. A. S. Bukhari, W. P. Cao, T. A. Soomro, and D. Guanhao, "Future of microgrids with distributed generation and electric vehicles," Development and integration of microgrids, vol. 55, 2017.

[17] IFC, "Environmental, Health, and Safety Guidelines," http://ifc .org/.

[18] World Health Organization, Evolution of WHO Air Quality Guidelines: Past, Present and Future, WHO Regional Office for Europe, Copenhagen, 2017. 
[19] REMA, "Inventory of Sources of Air Pollution in Rwanda Determination of Future Trends and Development of a National Air Quality Control Strategy," https://rema.gov.rw/ fileadmin/templates/Documents/rema_doc/Air\%20Quality/ Inventory $\% 20$ of $\% 20$ Sources $\% 20$ of $\% 20$ Air $\% 20$ Pollution $\%$ 20in\%20Rwanda\%20Final\%20Report..pdf.

[20] F. Un-Noor, S. Padmanaban, L. Mihet-Popa, M. N. Mollah, and E. Hossain, "A comprehensive study of key electric vehicle (EV) components, technologies, challenges, impacts, and future direction of development," Energies, vol. 10, no. 8, p. 1217, 2017.

[21] C. Mahmoudi, A. Flah, and L. Sbita, "An overview of electric vehicle concept and power management strategies," in 2014 International Conference on Electrical Sciences and Technologies in Maghreb (CISTEM), pp. 1-8, Tunis, Tunisia, 2014, November.

[22] K. Rajashekara, "Present status and future trends in electric vehicle propulsion technologies," IEEE Journal of Emerging and Selected Topics in Power Electronics, vol. 1, no. 1, pp. 3$10,2013$.

[23] L. Barote and C. Marinescu, "Li-Ion energy storage capacity estimation in residential applications with EV," in 2019 8th International Conference on Renewable Energy Research and Applications (ICRERA), pp. 326-330, Brasov, Romania, 2019, November.

[24] V. Shrivastava, "Research on structure for flywheel energy storage system in long lifetime UPS," International Journal of Engineering Research and Application, vol. 7, no. 11, (Part -3), pp. 16-21, 2017.

[25] Gautham Ram, "Roadmap Electric Vehicles and Grid Integration (V1G versus V2G)," http://www.pr-electronics.nl/en/ news/85/roadmap-electric-vehicles-and-grid-integration-vlgversus-v2g/.

[26] P. Paulraj, "SMART CHARGING 102: What are V1G, V2G and $\mathrm{V} 2 \mathrm{H} / \mathrm{V} 2 \mathrm{~B} / \mathrm{V} 2 \mathrm{X}$ smart charging? Integrating electric vehicles into power grid," https://www.emobilitysimplified.com/ 2019/12/what-is-vehicle-to-grid-v1g-v2g-v2x-v2h.html.

[27] NewMotion, "The future of EV charging with V2X technology," https://newmotion.com/en/the-future-of-ev-chargingwith-v2x-technology/.

[28] K. Wei, X. Dai, and P. Liu, "Model and balance of flywheel energy storage system with composite flywheel and rolling bearings," in 2017 IEEE Conference on Energy Internet and Energy System Integration (EI2), pp. 1-6, Beijing, China, 2017, November.

[29] C. Jin, X. Jiang, G. Zhong, and X. Li, "Research on coordinated control strategy of flywheel energy storage array for island microgrid," in 2017 IEEE Conference on Energy Internet and Energy System Integration (EI2), pp. 1-6, Beijing, China, 2017, November.

[30] A. A. El-Naga, M. I. Marei, and H. S. K. El-Goharey, "Second order adaptive notch filter-based wind power smoothing using flywheel energy storage system," in 2017 Nineteenth International Middle East Power Systems Conference (MEPCON), pp. 314-319, Cairo, Egypt, 2017, December.

[31] M. J. Chaudhry, "Enhancements in micro-grid operation through electric vehicle charging and discharging," in 2020 9th International Conference on Industrial Technology and Management (ICITM), pp. 245-250, Oxford, UK, 2020, February.

[32] S. Iqbal, A. Xin, M. U. Jan et al., "Role of power electronics in primary frequency control and power quality in an industrial micro-grid considering V2G technology," in 2019 IEEE 3rd
Conference on Energy Internet and Energy System Integration (EI2), pp. 1188-1193, Changsha, China, 2019, November.

[33] Transport \& Environment, "How clean are electric cars?," https://www.transportenvironment.org/what-we-do/electriccars/how-clean-are-electric-cars.

[34] World Bank, "Electric power transmission and distribution losses (\% of output)," https://datacatalog.worldbank.org/ electric-power-transmission-and-distribution-losses-output-1.

[35] H. Hao, M. Wang, Y. Zhou, H. Wang, and M. Ouyang, "Levelized costs of conventional and battery electric vehicles in China: Beijing experiences," Mitigation and Adaptation Strategies for Global Change, vol. 20, no. 7, pp. 1229-1246, 2015.

[36] B. Borlaug, S. Salisbury, M. Gerdes, and M. Muratori, "Levelized cost of charging electric vehicles in the United States," Joule, vol. 4, no. 7, pp. 1470-1485, 2020.

[37] The World Bank, Rwanda has achieved impressive development gains since the 1994 genocide and civil war, The World Bank supports the energy, agriculture and transport sectors, 2021, https://www.worldbank.org/en/country/rwanda/ overview.

[38] L. P. Nadimuthu and K. Victor, "Performance analysis and optimization of solar-powered E-rickshaw for environmental sustainability in rural transportation," Environmental Science and Pollution Research, pp. 1-2, 2021.

[39] N. Kamalimeera and V. Kirubakaran, "Prospects and restraints in biogas fed SOFC for rural energization: a critical review in Indian perspective," Renewable and Sustainable Energy Reviews, vol. 143, p. 110914, 2021.

[40] Z. Wang, Y. Tang, X. Chen, X. Men, J. Cao, and H. Wang, "Optimized daily dispatching strategy of building-integrated energy systems considering vehicle to grid technology and room temperature control," Energies, vol. 11, no. 5, article 1287, 2018.

[41] J. Ben Hmida, M. Javad Morshed, J. Lee, and T. Chambers, "Hybrid imperialist competitive and grey wolf algorithm to solve multiobjective optimal power flow with wind and solar units," Energies, vol. 11, no. 11, p. 2891, 2018.

[42] D. Liu, Q. Zhong, Y. Wang, and G. Liu, "Modeling and control of a V2G charging station based on synchronverter technology," CSEE Journal of Power and Energy Systems, vol. 4, no. 3, pp. 326-338, 2018.

[43] S. Al-Sakkaf, M. Kassas, M. Khalid, and M. A. Abido, "An energy management system for residential autonomous DC microgrid using optimized fuzzy logic controller considering economic dispatch," Energies, vol. 12, no. 8, p. 1457, 2019.

[44] U. Abronzini, C. Attaianese, M. D’Arpino, M. Di Monaco, and G. Tomasso, "Cost minimization energy control including battery aging for multi-source EV charging station," Electronics, vol. 8, no. 1, p. 31, 2019.

[45] Z. Zhao, J. Guo, C. S. Lai, H. Xiao, K. Zhou, and L. L. Lai, "Distributed model predictive control strategy for islands multi-microgrids based on non-cooperative game," IEEE Transactions on Industrial Informatics, vol. 17, pp. 38033814, 2020.

[46] H. Hou, M. Xue, Y. Xu et al., "Multiobjective joint economic dispatching of a microgrid with multiple distributed generation," Energies, vol. 11, no. 12, p. 3264, 2018.

[47] G. Saldaña, J. I. San Martin, I. Zamora, F. J. Asensio, and O. Oñederra, "Electric vehicle into the grid: charging methodologies aimed at providing ancillary services considering battery degradation," Energies, vol. 12, no. 12, p. 2443, 2019. 
[48] L. Yu, T. Zhao, Q. Chen, and J. Zhang, "Centralized bi-level spatial-temporal coordination charging strategy for area electric vehicles," CSEE Journal of Power and Energy Systems, vol. 1, no. 4, pp. 74-83, 2015.

[49] D. Liu, Y. Wang, and Y. Shen, "Electric vehicle charging and discharging coordination on distribution network using multi-objective particle swarm optimization and fuzzy decision making," Energies, vol. 9, no. 3, p. 186, 2016.

[50] R. Shi, S. Li, C. Sun, and K. Y. Lee, “Adjustable robust optimization algorithm for residential microgrid multi-dispatch strategy with consideration of wind power and electric vehicles," Energies, vol. 11, no. 8, p. 2050, 2018.

[51] H. Liu, Y. Ji, H. Zhuang, and H. Wu, "Multi-objective dynamic economic dispatch of microgrid systems including vehicle-togrid," Energies, vol. 8, no. 5, pp. 4476-4495, 2015.

[52] Y. Zhou, A. Vyas, and D. Santini, "Tracking national household vehicle usage by type, age, and area in support of market assessments for plug-in hybrid electric vehicles," Journal of Transportation Technologies, vol. 3, no. 2, pp. 174-183, 2013.

[53] K. S. Reddy, S. Aravindhan, and T. K. Mallick, "Techno-economic investigation of solar powered electric auto-rickshaw for a sustainable transport system," Energies, vol. 10, no. 6, p. 754, 2017.

[54] Homer energy, "HOMER Grid," https://www.homerenergy .com/products/grid/index.html\#: :text=HOMER\%20Grid\% 20lets\%20you\%20accurately,tiered\%20rates\%2C\%20and\% 20 much $\% 20$ more.\&text=Our\%20experts $\% 20$ are $\% 20$ also $\%$ 20 available,you $\% 20$ need $\% 20$ for $\% 20$ accurate $\% 20$ modeling. 